\title{
Tocqueville and Lower Canadian Educational Networks
}

\author{
Bruce Curtis \\ Sociology and Anthropology, Carleton University, Canada
}

\begin{abstract}
Educational history is commonly written as the history of institutions, pedagogical practices or individual educators. This article takes the trans-Atlantic networks of men involved in liberal political and educational reform in the early decades of the nineteenth century as its unit of analysis. In keeping with the author's interest in education and politics in the British North American colony of Lower Canada, the network is anchored on the person of Alexis de Tocqueville, who visited the colony in 1831. De Tocqueville's more or less direct connections to many of the men involved in colonial Canadian educational politics are detailed.
\end{abstract}

Key words: de Tocqueville, liberalism, educational networks, monitorial schooling.

\section{RESUMEN}

La historia educativa se escribe comúnmente como la historia de las instituciones, de las prácticas pedagógicas o de los educadores individuales. Este artículo toma, como unidad de análisis, las redes transatlánticas formadas por hombres implicados en las reformas liberales políticas y educativas durante las primeras décadas del siglo XIX. En sintonía con el interés del autor en la educación y la política en la colonia Británico Norteamericana de Lower Canadá, la red se apoya en la persona de Alexis de Tocqueville, que visitó la colonia en 1831. Las relaciones de Tocqueville, más o menos directas, con muchos de los hombres implicados en política educativa del Canadá colonial son detalladas en este trabajo.

Descriptores: De Tocqueville, Liberalismo, Redes educativas, Enseñanza monitorizada.

\section{RÉSUMÉ}

L'histoire de l'éducation est ordinairement écrite comme histoire des institutions, des pratiques pédagogiques ou d'éducateurs particuliers. Cet article prend comme unité d'analyse les réseaux transatlantiques de personnes impliquées dans la réforme libérale politique et éducative durant les premières décennies du dix-neuvième siècle. Selon l'intérêt de l'auteur pour l'éducation et la politique dans la colonie nord-américaine britannique du Lower-Canada, le réseau est ancré dans la personne d'Alexis de Tocqueville, qui a visité la colonie en 1831. Les connexions plus ou moins directes de Tocqueville avec un bon nombre d'hommes liés à la politique de l'éducation dans la colonie canadienne sont exposées en détail.

Mots-clés: de Tocqueville, le libéralisme, les réseaux de l' éducation, le contrôle de l'enseignement, l'instruction surveillée. 
$\mathrm{E}$ ducational history is most commonly written as the history of systems of instruction, of instructional methods or practices, or as the biography of individual educators. This exploratory essay takes transatlantic educational networks of the 1830 s as its object of analysis. It anchors itself in the British North American colony of Lower Canada, but it is partly inspired by recent tendencies across the disciplines to think in terms of the Atlantic world as a unit of analysis, paired with attention to the importance of imperial relations. Transatlantic networks in the nineteenth century field of education were fostered by waves of tourism, semi-official reporting and official investigation which gained momentum after the Napoleonic Wars and which resulted in a large and widely-circulated volume of publications. By the middle 1830 s, there was a well-established European educational circuit that included schools in Dublin, Glasgow, Edinburgh and London, de Fellenberg's Höfwyl, and the schools in several parts of Prussia. European visitors were fascinated by American common school systems. Men and women circulated through this network, but ideas and practices did as well. ${ }^{1}$

As soon as one begins to trace networks of contact, acquaintance and influence in the educational field, it quickly becomes obvious that everyone was connected to everyone else. Some connections are much more easily traced than others, and far more documentation survives about male intellectuals, state servants, and capitalists, than about farmers and artisans, teachers and trustees. The account I offer here of networks anchored in Lower Canada is limited by its inattention to the latter, but also by inattention to connections among women, and to connections among men that were mediated by relations to women. Similarly, I have little to say about the domestic. I am mindful that kinship relations and family, on the one hand, and the organization of domestic life on the other, ground structures of connectedness, and make it possible for men to engage in educational agitation, innovation and politics.

Both lay and religious women in Lower Canada ran schools and managed such educational institutions as the convents in Quebec and Montreal, and the urban Infant school societies. In doing so, they connected themselves to transatlantic networks as their male counterparts did. The Montreal Infant School Society, for instance, was initially an offshoot of a project sponsored by the British and Foreign School Society (BFSS) in London. The Methodist missionary Thaddeus Osgood had raised a substantial sum for his Society for promoting Education and Industry among the Indians and destitute Settlers in Canada in the early 1820s, and he interested several upper class women in Montreal in infant schooling. They opened an experimental school for pauper children in conjunction with the School of Industry in 1829, and formalized their work by forming an Infant School Society the following year. They corresponded directly with the BFSS in search of a trained teacher. By being connected to the BFSS, women in Montreal connected themselves to the infant school pioneer, Samuel Wilderspin, and through him to his extensive international connections. ${ }^{2}$ Most of the Lower Canadian school societies were presided over and managed by elite men; most also contained a school for younger children presided over and managed by women married to elite men. Still, documenting the existence of social connections among men informs us about some dimensions of the field which framed educational practices and initiatives. 
Attending to transatlantic networks offers some escape from the parochialism that has characterized much of the historiography of Lower Canadian education. Modest in volume, that historiography has sought commonly to understand what happened in Lower Canada by focusing on religious, cultural, and political events in the colony itself, even if the imperial government is often invoked as a leading actor. Yet in the domain of education and beyond, Lower Canada was a proving ground, at times quite explicitly, for policies and practices that worked or were believed to work in other parts of the world. Furthermore, the fate of particular educational initiatives in the colony was determined at times by political events on the world stage. A good example is the systematic and tenacious refusal of the Lower Canadian Catholic bishops to countenance non-sectarian common schooling in the late 1830s on the model accepted enthusiastically by the Irish Catholic bishops in the middle 1820s. Between the acceptance of the model by the Irish hierarchy and the refusal of it by the Canadian, there intervened the Spanish War of Succession, in which the English Whig government supported the liberal party. Its uncompromising determination to separate church and state and willingness to engage in spoliation turned the Vatican sharply against liberalism and against projects aimed at producing civil harmony through a generic Christian schooling. ${ }^{3}$

\section{Educational Network}

Network analysis bases the 'anchor' or point of departure for the investigation of a network on the interest of the analyst. My work is preoccupied with attempts in Lower Canada especially from the late 1820 s to govern the colony liberally, through educational means. Educational projects were inextricably political projects, caught up with wide-ranging attempts to generate a populace that could be governed actively through its cultivated intelligence. While traces of archaic mercantilist views, in which the poor and the peasantry were to be kept moral through innocent ignorance, were still very much present in Lower Canada, even among republicans, the necessity of basing rule on the disciplined will of a free people was very much at the fore in the 1830s. Perhaps the single most influential work on liberal democratic politics of the 1830s was Alexis de Tocqueville's Democracy in America and I begin with de Tocqueville.

While touring northern New York state with his companion Gustave de Beaumont, Tocqueville learned to his surprise that a French enclave survived on the banks of the St. Lawrence and at the end of August 1831 he and Beaumont visited. ${ }^{4}$ The two were meant officially to be investigating American penal practice and, while Beaumont would report on these matters, their sociological and political curiosity engaged them in examinations of the larger cultural, political, and economic questions of democratic government. Local democratic management of free schools was seen by them as one way in which American democracy survived without falling into anarchy in the absence of a state religion. An American contact passed the two men on to the Montreal lawyer Charles Mondelet, who toured them around briefly, before sending them on to John Neilson in Quebec. Neilson also led his French guests around the city and neighbourhood, although apparently they escaped him long enough to question some habitans by themselves. ${ }^{5}$ 
Tocqueville, deeply Catholic and French in his loyalties, was impressed by Lower Canada, both on the spot and later in reflection. It seemed to him like a museum. On the one hand, as aristocrat and landowner, he was charmed by the warmth, hospitality, and morality of the peasantry. On the other hand, the colony served him in his published work as the mirror image of American democracy. As he would write in Democracy in America, 'the habit of thinking and governing for oneself is indispensable in a new colony,' but there seemed to be little of this in Lower Canada, where the mass of the French population was subordinated to curé, seigneur, and agricultural routine. The presence of local, electorally managed institutions in New England seemed to him to account for much of the striking difference in economic and commercial development between Lower Canada and the American states. Yet he would continue to reflect on the relations between 'civilization' (the growth of commerce and the division of labour) and morality in the rest of his travels. ${ }^{6}$

Tocqueville's Lower Canadian hosts were actively involved in colonial politics and reform. When Tocqueville and Beaumont arrived in Quebec city, John Neilson, MPP, a prime mover in the Assembly's Permanent Committee on Education, had just returned from inspecting the rural schools in his county and was about to write a critical report on the operation of the Assembly's Trustees School Act, passed in 1829. Neilson's 1831 report highlighted the flaws in this ambitious plan for schooling which, at this moment, had the support of both legislative and executive branches of government. From a lack of systematic administrative oversight, he showed that local trustees and teachers were engaging in a range of dubious practices, such as falsifying the class roll or demanding two grants for married couples teaching a single school. Many schools were too small to be viable. Among other things, Neilson's report urged the arrangement of rural school districts in such a manner that it would be possible to adopt the monitorial method elaborated by Joseph Lancaster. ${ }^{7}$ Neilson was a staunch advocate of monitorial schooling throughout the 1820s and 1830s. He visited the British and Foreign School Society's Borough Road model school when he was in London in 1835. As a member of the managing committee of the Quebec Normal School in 1836, it was likely Neilson who urged the committee's emissary, the abbé Jean Holmes, to canvass European opinion on monitorial methods. As a member of the Special Council in 1839, Neilson would sponsor the ordinance that aimed to divide Lower Canada into three educational inspectorates.

It was around the broader question of the development of administrative capacity in the colonial state system that the Mondelet brothers fell out with the majority patriote party in the colonial Assembly. There were no government administrative departments of much substance in the colony. The work of administering legislative projects, such as funding for transportation infrastructure and the Trustees School Act, fell entirely on the offices of the Provincial Secretary, the Inspector General and the Receiver General. Their administrative oversight was largely financial, and in the case of the schools, was limited to verifying formal compliance with funding rules. There was no educational administrative agency with discretionary power and, in the political climate of the middle 1830s, most discretionary action on the executive's part led to violent attacks from the legislature. John Neilson's Permanent Committee attempted to specify 
administrative procedures for the rural schools, but it could provide no day-to-day oversight. The Assembly sought to make its own members responsible for educational administration in their ridings, but individual MPPs devoted varying degrees of energy to the work, and their control over discretionary school monies was complained of as political patronage. In the later 1830s, the Assembly simply disregarded the considered advice of its own committee.

The government offices were stretched by administrative demands: there were over nine hundred elementary schools by 1836 , and there were major gaps among policy formation, administration and legislation. The patriote party had agreed with Governor Aylmer that having a legislative voice in the executive government was a wise move and had allowed Philippe Panet to sit in both venues. In the increasingly venomous atmosphere after 1834, however, when Dominique Mondelet agreed to replace the deceased Panet, he was denounced by the majority as spy for the executive in the legislature and unseated. Neilson had fallen out with the patriote party earlier, convinced that the imperial government was granting needed reforms. In April 1834, Neilson and Dominique Mondelet were commissioned by Governor Aylmer to investigate and report on American penitentiaries. They replicated part of the American tour conducted by Beaumont and Tocqueville. ${ }^{8}$ For his part, Charles Mondelet published a series of letters on education in the press in 1840, agitating for a public education system close to that recommended in Lord Durham's Report on the Affairs of British North America. He also proposed to translate Peter Parley's geography textbook into French, since there wasn't a good French language geography in the colony. ${ }^{9}$ At the same time, Neilson's 1831 report on schools was taken up by the secretary to Durham's Education Commission, Christopher Dunkin, as one proof among many of the corrupt and degraded educational system sponsored by the colonial Assembly. ${ }^{10}$

Alexis de Tocqueville left America shortly after his Lower Canadian visit, but continued his enquiries into government, culture and politics as he thought through what he had seen in America. He was in England in 1833 and again in 1835; in the latter year he also toured Ireland, still making notes and preparing the second volume of Democracy. His appreciation of the simple morality and material comfort of the French Canadian peasantry contrasted sharply with his reactions to the moral degradation, loose sexual morality and widespread bastardy worked by the operation of the English Poor Laws and by the astonishing contrasts of wealth and misery in industrial Manchester. His observation of peasant morality in Ireland intrigued him further. He wrote a long note on,

How it is sometimes necessary to Distinguish Good Morals from Prudery. In Ireland, where almost no children are born out of wedlock and where in consequence morals are very pure, women take less trouble about covering themselves than in any other country in the world and men appear to have no repugnance at showing themselves almost naked. I saw young girls bathing completely naked in the sea, only a short distance away from young men. In England, where I am led to believe that one eighteenth of births are illegitimate, and where the morals of the lower classes are decidedly loose, prudery is carried to the point of being a ridiculous affectation. Does what is called prudery thus come 
more from the state of civilization than from that of morality? Or is outward prudery a combination of the two? Perhaps extreme prudery comes from extreme civilization joined to fairly strict and regulated morality? It would be worth digging deeper into this. ${ }^{11}$

Tocqueville was also struck by the popular enthusiasm for schooling among the Irish Catholic peasant population, despite its miserable poverty, something that contrasted sharply with the indifference of the French-Canadian peasantry. He visited schools and in co. Tuam had a long conversation with a priest who was supporting the English government's new educational system, even though it excluded sectarian religious instruction from the schoolroom. This system, which liberals in England had promoted for that country, but whose adoption there was blocked by sectarian struggles, was suggested both by the Gosford Commission and by the Durham Mission for Canada, and it formed the basis of much of the Canadian school legislation in the 1840s. Wasn't the priest worried about Protestant conversion, Tocqueville wondered? Education first, the priest argued, Ireland desperately needed education and, anyway, he got the children as soon as they came outside class. His bishop agreed. ${ }^{12}$

Tocqueville corresponded at length with J.S. Mill and during his second visit he spent time with Mill and J.A. Roebuck, the latter raised in Lower Canada and soon to be the Assembly's English agent, discussing, debating and assessing the substance of the young men's political Radicalism and their strategic situation in party politics. The first volume of Democracy was reviewed favorably and at length by Mill in October 1835, and Mill had also reviewed Sarah Austin's translation of Victor Cousin's report on Prussian schools. Mill was communicating directly with Cousin, who was trying to get information about the methods of the British and Foreign School Society's training institution in the Borough Road, London.

The earlier incarnation of the British and Foreign School Society, the Royal Lancasterian Institution, had enjoyed the enthusiastic support of J.S. Mill's father's circle. His father James Mill, John and Sarah Austin and Jeremy Bentham in fact shared a back garden. Bentham either designed or proposed to design a school in the garden in the form of a panopticon, in which the younger Mill had some of his early schooling. ${ }^{13}$ The school, which Bentham used in his educational utopia, Chrestomathia, employed a version of the monitorial method of instruction elaborated by the Quaker Joseph Lancaster. After Lancaster himself was ousted and sent off to America, his Royal Institution became the British and Foreign School Society (BFSS).

Lancaster's methods were published in the Quebec press as early as 1808 , and in 1815 the Lower Canadian Assembly moved to subsidize the printing and distribution of 1500 copies of a description of his methods. Already in 1814 there was an attempt by a group involved in the BFSS to advance the education of the poor in Quebec and the Quebec Free School was founded shortly after, under the direction of Thaddeus Osgood. The school closed for lack of funds in 1817, but Osgood returned to England and managed to raise a substantial sum to promote monitorial schooling for the Canadian Indian population. The Free School was succeeded by the Société d'Éducation de Québec, which used monitorial methods but which, under the supervision of the 
curé of Quebec, refused Lancaster's practice of scripture reading 'without note or comment.' A second monitorial school conducted in French was managed by the Société d'Éducation des Trois Rivières from 1830. The BFSS had Canadian offspring in the Quebec and Montreal British and Canadian Schools, which were organized in 1823 and 1822, and both later had infant schools associated with them. The schools imported teachers from the BFSS's London central school and, in the middle 1830s, the Assembly was offering them extra funds to train monitorial school teachers. The Anglicans, whose National Society for Promoting the Education of the Poor in England and Wales in the Principles of the Established Church outstripped the BFSS in England by 1815, also organized a National free school in Quebec and in Montreal which used Andrew Bell's version of monitorial schooling, but the schools were less popular than those of the BFSS.

All these institutions were managed by boards of directors. The boards point to the existence of elite networks focused on the free instruction of pauper children in the colonial towns and cities and they provided occasions for the ruling groups to associate publicly while demonstrating leadership. Moreover, because support for different versions of urban pauper schooling within the ruling groups was often divided along lines of religion and ethnicity, the membership of the boards provides insight into political conflict over school policy. Especially before 1829, while the imperial government still entertained the fantasy of control over popular schooling by the Anglican church, or by the Anglican and Catholic churches together, the lay/religious divide was sharp and some individuals who attempted to bridge it suffered vituperation, although others managed. The Société d'Éducation de Québec was under the close supervision of the Catholic hierarchy, while the Quebec Central National School was managed by the Quebec diocesan committee of the Society for Promoting Christian Knowledge. The British and Canadian Schools were supported by a cross-section of the ruling groups, but were formally non-sectarian. Their Quebec secretary, Jeffrey Hale, whose father was Receiver-General, nonetheless also acted as Canadian secretary to the British and Foreign Bible Society.

The wealthy Quebec prothonotary, Joseph-François Perrault, served as first president of the Société d'Éducation and then as first president of the British and Canadian School (thereby earning the wrath of the Catholic hierarchy), before constructing a large and innovative monitorial school at his own expense. The school was a magnet for visitors and it modified Lancaster's methods to include industrial training for boys and domestic craft training for girls under the direction of local artisans. ${ }^{14}$ Perrault subsidized the school heavily out of his own pocket, giving the students pocket money to attend, and engaging in a host of other educational initiatives. These included the translation and publication of his version of Lancaster's method and a more or less complete series of schoolbooks. Perrault hatched a plan for an agricultural college, which he launched, but which survived only for the year 1832-3. The school director was a recent Swiss immigrant named Amury Girod, who had studied with de Fellenberg at Höfwyl and who had been agitating for the establishment of a set of similar institutions in Canada. Girod became disaffected politically and led the insurgent forces at St Eustache during the 1837 Rebellion. He committed suicide to avoid capture. ${ }^{15}$ 
In 1833, Perrault drafted an elementary school bill that contained clauses for the creation of non-sectarian schools supported by property taxation and managed by central boards of education. He was denounced roundly in the press for advocating a police state measure and the opposition of the Catholic hierarchy to him intensified markedly. When the bill failed, he attempted to have the Assembly take over his school and later to have the Quebec Normal School Board adopt his monitorial schooling plan as the basis of normal schooling and, indeed, to hire him as normal school master, but his advanced age, apart from clerical and patriote party antipathy, made this unlikely. Nonetheless, Perrault was partly responsible for John Neilson's enthusiasm for monitorial schooling and Neilson occupied an important position in colonial educational networks before he broke definitively with the patriote party in 1834 . His influence was felt again later, both on the Normal School Board and on Colborne's second Special Council, which dictated Lower Canadian legislation after the suspension of civil liberties.

Neilson, Perrault, the patriote leader Louis-Joseph Papineau and other members of the Lower Canadian elite on both sides of the ethnic/political divide were enthusiastic initial supporters both of monitorial schooling and of Joseph Lancaster, who was himself in Montreal from September 1829 until late May or early June 1833. Lancaster arrived in the colony shortly after the coming into effect of the Assembly's Trustees School Act and quickly claimed that funding his remarkable experiments in education would lead to an educated nation in a very short space of time. Lancaster charmed Papineau, with whom initially he had warm relations, and Papineau passed on Lancaster's written versions of his plans and schemes to Neilson. Lancaster's communications with the patriote leaders were transmitted on occasion by the Tory George Moffat, and some Montreal Tories apparently sent their children to him. At Papineau's instigation, Lancaster was voted $£ 200$ by the Assembly in 1831 and 1832 , more in one of those years than J.-F. Perrault, even though Lancaster's school was smaller, if it actually was a school for long. Perrault and Lancaster were almost certainly acquainted personally, for not only was Lancaster frequently in Quebec, but also the two agitated before the Executive Council at the same period for the passage of a colonial copyright law to protect their educational publications. ${ }^{16}$

Lancaster fell afoul of Papineau and the rest of the patriote majority in the course of the controversial 1832 Montreal West election campaign. Lancaster claimed after the fact that he had asked Papineau if he was qualified to vote, and was told by him and by other patriote leaders that could but he must vote for their candidate, Dr. Tracey, or lose his parliamentary subsidy. Not only did Lancaster come to the poll in the company of two young arch-Tories to vote for the Tory Bagg, but after the election deteriorated into a riot that culminated in troops firing on the assembled crowd and killing three patriote party supporters, Lancaster hastened to Quebec to warn Governor Aylmer of the seditious goings-on of the French Canadian party and promised to act as an informant. He denounced the behaviour of Papineau and other patriotes during the coroner's inquest and warned the governor of impending revolution. If this were not enough to separate him from his French-Canadian supporters, his reputation was further injured by his outlandish comportment in the cholera epidemic that broke out in June 1832. Still, for 
much of the 1830s in Lower Canada, it was to Lancaster's pedagogy that politicians looked for the substance of a school system. ${ }^{17}$

The English Whigs and Radicals with whom Tocqueville visited and corresponded were not limited to J.S. Mill and J.A. Roebuck, although Lower Canadian patriote politicians might have profited from Tocqueville's comments on the latter. As Lower Canadian politics dissolved into trench warfare over the Civil List and the question of an elective Legislative Council, patriote party analysis of the stance of the English government was said to be that of the Assembly's agent, Roebuck. While Tocqueville commented on Roebuck's earnestness for reform, and his respect for property and religion, he also noted his marginal social position and the fact that his political situation depended on 'continually keeping the people's passions in motion. ${ }^{18}$ Those passions would fail him in the 1837 elections and well before that he had been unable to rouse much interest in Lower Canadian grievances in the Commons.

Tocqueville corresponded at length with the political economist Nassau Senior and Mill served as an intermediary between Tocqueville and Edward 'Bear' Ellice (although it seems they did not manage to meet when Ellice was in Paris). Ellice was the seigneur of Beauharnois, south-west of Montreal, and for much of the 1820s and 1830s a leading voice in governing circles on Canadian questions. He was an intimate of Lord Durham and it was likely at Ellice's urging that Durham was convinced to undertake his ill-fated mission to Canada in the wake of the first wave of the 1837 Rebellion. In Canada in 1836, Ellice was in frequent contact with his fellow seigneur for St. Charles, Pierre-Dominique Debartzch, and through him with others disaffected with the radical politics of the Papineau faction. Ellice reported his meetings with Debartzch to the English cabinet, discussing how best to manage Lower Canadian politics and urging the creation of a form of ministerial government with 'a discreet division of the loaves and fishes' to include the appointment of Louis-Joseph Papineau to the office of President of the Executive Council, or as Attorney-General. He also stressed the dangerously high level of illiteracy among his French-Canadian tenant farmers, writing 'not one in a bundred can write his name. I had an Address from a whole Parish the other day in which the Notary was obliged to attest "the mark" of every subscriber. ${ }^{19}$ The English Radicals and Whigs would attribute much of the source of Lower Canadian unrest to the illiteracy that subjected the peasantry to demagogic political agitation.

Ellice's son Edward Jr. was taken to Canada by Lord Durham as his private secretary in 1838 and Durham and Lady Durham spent several nights at Beauharnois in late July. Ellice Jr. was taken hostage on the night of 3 November when the patriote forces seized the Beauharnois manor house; his wife Jane Ellice's diary offers some invaluable insight into the domestic life of the Durham mission, and into the liberals' reactions to Canada and Canadians as well as to America and Americans. ${ }^{20}$

Through Mill, Tocqueville would also later come into contact with Charles Buller, MP, Durham's Chief Secretary in Canada, who would act as the English correspondent for Tocqueville's newspaper in the mid 1840s. Indeed, Tocqueville noted after their first meeting in October 1844, 'I saw Mr. Buller here and I was not only pleased but rather enchanted by him. He as a fine and lofty mind and, if I am not mistaken, his heart is very much in the right place. ${ }^{21}$ While Buller travelled to Canada with Durham, 
J.S. Mill followed the mission's progress from England and was prepared to defend it in print, even after its nature as a fiasco should have been evident. Several members of the mission, although perhaps not Durham himself, had read Tocqueville's Democracy volume closely and it formed part of the mission's library, but the theoretician in the group was Charles Buller. It was Buller who wrote with most lucidity and eloquence on the necessity for local representative self-government as an indispensable training for what he regarded as the inevitability of colonial independence. It is probably Tocqueville via Buller that readers of Durham are exposed to in the sections of his report dealing with local government. ${ }^{22}$

Charles Buller and his dandyish and perhaps feckless younger brother Arthur, who chaired Durham's Education Commission, came from an extremely wealthy AngloIndian family. They were tutored by Carlyle and their parents' household was regularly visited by the leftish British intelligentsia, including Dickens, Mill, Thackeray, Darwin, Browning, Macready, Harriet Martineau and so on. Charles was one of the 1820s Cambridge Apostles, and at the end of the decade when he went to study law at Lincoln's Inn he joined a political study group that included George Grote, Mill, Roebuck and George Graham. He studied law at the Utilitarians' London University under John Austin as soon as it opened

Charles Buller, as did the others around Durham, had taken James Mill's Essay on Government as his political bible and, by the late 1830s, he and the younger Mill were increasingly close as they moved towards greater political moderation. In his parliamentary career, Buller undertook two particularly noticeable initiatives. He chaired the Records Commission, which reviewed the government's intelligence generation and information storage and retrieval mechanisms. The commission was partly a means to justify the formation of a statistics branch at the Board of Trade, under Poulett Thomson, later Lord Sydenham, who would follow Durham as Canadian governor. Yet it was also partly an argument for the necessity of a public records office and a venue for discussion and debate on the part of those concerned with the generation of the social intelligence necessary for rational administration. Witnesses before the commission testified at length about the means for generating reliable intelligence, the techniques of what was becoming known as 'the social science.' Buller was close to, if not actually a member of the London Statistical Society, formed in 1834, and Nassau Senior was both a leading member of the Society and an important witness before the Records Commission. He discussed at some length the relative merits of different techniques of enquiry by which centrally-situated investigators could learn of local conditions. Buller's other parliamentary initiative concerned the management of parliamentary business; he worked successfully to get what was called 'parish business' off the parliamentary agenda by passing it to local government and the necessity of doing so was one argument underlying the English 1835 Municipal Corporations Act. ${ }^{23}$

As Chief Secretary in Canada, it was Charles Buller who organized the Durham Mission's intelligence gathering projects, in addition to working to keep the unstable Durham on an even keel, and it was Buller who agitated for a union of all the British North American colonies, rather than the union of the two Canadas Durham eventually proposed. When one reads Durham or Sydenham arguing that the colonial state 
was powerless because it attempted to manage local parish business, when one hears them maintain that state power could best be preserved by being dispersed, one is hearing arguments articulated most clearly by Charles Buller.

The Durhamites came to Canada prepared to finish off one important piece of business left undone by the Gosford Commission, sent to report on Lower Canadian grievances in 1835-6: the adoption of some version of the Irish school system in the colony. The earlier commission had been expressly charged with investigating educational conditions and with making a start on needed reforms, ${ }^{24}$ but it was far too preoccupied with a general reorganization of the state system to spend much time on schooling. Nonetheless, the Gosford Commission's final report analyzed the history and current condition of the colony's schools and outlined the basic elements of what it saw as a sound school system. The commissioners pointed out that between 1829 and 1836, the Assembly had expended ' $£ 172,519.5 .9$ [,] being on an average $£ 24,465.14 .3$ per annum, or about $1 / 5$ th of the total Revenue of the Province' on elementary schooling, a huge amount whose meager results underlined the necessity of a reformed school system. This system should be supported by a small central grant, but the bulk of the funding should come from locally raised school taxes and student fees, and it should be supervised by boards of education established in each of the three colonial districts. The commissioners were somewhat timid on the matter of religious instruction in the schools, but insisted the system needed to be 'comprehensive', which meant that instruction could not lead to the exclusion of any religious group. The commissioners argued that the arrangements for education in Ireland should be publicized in the colony and expressed their satisfaction that Lower Canadians were becoming familiar with Victor Cousin's work on Prussian schools. ${ }^{25}$

Arthur Buller chaired Durham's Education Commission, although he left the colony with the rest of the Durham suite well before the commission's investigations were complete. His report's final recommendations echoed those described in outline by the Gosford Commission. The Durham commission's importance lay in its attempt to create a systematic inventory of existing educational resources, to map on the ground the contours of a reformed system, and to generate statistical resources that would make it possible to engage in educational planning. Although it failed miserably, both because the second wave of rebellion broke out in its midst, and because the Catholic hierarchy instructed the clergy not to cooperate, the commission's enquiry was the most sophisticated statistical investigation undertaken in the colony. ${ }^{26}$ Even with the slender information he could glean, the commission's secretary, Christopher Dunkin, attempted to determine school catchment areas and to project school financial needs across a five year horizon. No Lower Canadian educational activist had thought so systematically about school administration.

Dunkin had been editor of the Montreal Morning Courier, whose line on Canadian questions in 1837 was consistently reproduced in such liberal English papers as the London Morning Chronicle. Imperial politicians had learned to play with press propaganda by the late 1830s. Gosford recommended the Morning Courier to Durham as an appropriately liberal and moderate political mouthpiece on 30 June 1838, but already by that time it was an organ for the governor. ${ }^{27}$ Dunkin is best known as federal 
Minister of Agriculture, a position from which he was forced to resign in the wake of the 1871 census, and as the first Finance Minister for Quebec, but he got his start in political administration with Durham's Education Commission and followed it with work for Sydenham's postal commission before leaving state administration to study the law. His influence on the formation of state schooling in Canada has been almost completely neglected. As secretary to the Education Commission, it was in fact Dunkin who managed the commission's enquiry and who wrote its final report. It was Dunkin's recommendations that formed the basis of what Arthur Buller wrote on education in Lord Durham's report. These recommendations were taken up in turn by the Lower Canada Special Council in 1839. Dunkin wrote a detailed critical account of the history of schooling in the colony, compiled a huge manuscript history of the Jesuits' Estates, and published an analytic account of Canadian politics in the Rebellion period. It was Dunkin who drafted the 1841 School Bill presented to the United Canadian parliament by Charles Dewey Day, and it was provisions in that draft bill, initially lost in the legislature, that Egerton Ryerson restored in his 1846 Canada West School Act. That act, in turn, modified in 1850, served as the basis of public education in Ontario for more than a century and shaped legislation in several other provinces as well. ${ }^{28}$

Christopher Dunkin was born near London in 1811 or 1812 and died in 1880 in Knowlton Quebec. His mother was widowed while he was young and eventually married an American literature professor, Dr. Johnathan Barber, who moved the family to Massachusetts in 1831 or 1832 . Dunkin, who had been at university at Glasgow in 1830-1, where he won the class prize in Logic, took a teaching job at Harvard and married his step sister, but he provoked a student revolt and left the university after a face-saving year and the awarding of a degree. His father bought the Morning Courier as a speculation, and Dunkin edited it from early 1837. Dunkin's entry in the Dictionary of Canadian Biography (XI:286-8) notes that he studied at Glasgow, and the Glasgow University matriculation register contains some further information. However, neither source mentions that Dunkin was enrolled in the University of London in November 1829 and paid his fees for instruction in Latin, Greek, Mathematics, and English. Edward Ellis [Ellice Jr.] was enrolled in the same course, while the classes in Jurisprudence included J.A. Roebuck, Edwin Chadwick, and Charles Buller. John Stuart Mill had been in the 1828 Jurisprudence class and Charles Macaulay was in the junior course in modern languages and mathematics. ${ }^{29}$ These people may never actually have encountered Dunkin, but it is likely that Ellice at least had heard of him. When the Durhamites looked for a press mouthpiece in Montreal they found one of their own already in place: the network looped back on itself.

There is one final set of linkages that will complete this brief exploration of transatlantic connections. While Charles Buller, John Stuart Mill, and J.A. Roebuck shared aspirations for the advancement of the Radical party in England, they disagreed sharply over colonial questions. Indeed, as William Thomas has shown, Roebuck's ineffectiveness as the Lower Canadian Assembly's agent was due in part to a division over colonies among radical Whigs more generally. ${ }^{30}$ There were two positions open to the Radicals in keeping with the political theory of James Mill: either, as David Ricardo argued, colonies could be denounced as useless economic burdens on the imperial country, or 
one could argue as did Mill on India that colonies provided occasions for the spread of civilization. From the late 1820s, the second position was developed by Edward Gibbon Wakefield into the argument for 'systematic colonization.'

Largely forgotten now, Wakefield's propositions were thought sufficiently significant in the nineteenth century for Karl Marx to devote the final chapter of the first volume of Capital to their refutation. ${ }^{31}$ Wakefield argued that capitalist development could be engineered in colonies, and surplus English labour and capital employed, by selling agricultural land at upset prices to new immigrants. Land prices would be set sufficiently high to ensure that poor immigrants would have to work for wages before being able to purchase it. Capitalist farmers would thus be relieved of the notorious labour shortages that drove up colonial wages. The revenue generated by land sales would constitute an immigration fund, and government would select young married couples to ship to the colonies, since they would make the most industrious and loyal colonial subjects. The Colonial Office was never willing systematically to get involved in the direct organization and finance of emigration. But versions of the scheme had broad support in English political circles, including from Buller and Mill.

In a variation on the theme, some English groups sponsored the formation of private land companies to purchase colonial lands in pursuit of systematic colonization. The land companies would provide the necessary infrastructure for the working of a colonial market economy in the shape of roads, bridges and perhaps public buildings, but they were meant to be profitable. Early attempts were made in South Australia, initially via a National Colonization Society, soon renamed the South Australia Association, but the government took over land sales in the colony in 1834. A second attempt was made through the New Zealand Company, in which Durham, Buller and Wakefield were investors.

That some version of 'systematic colonization' was to be official policy in Lower Canada was announced by the Colonial Office to governor Aylmer in 1831. 'To restrain in some degree the extreme facility of acquiring land, by demanding a moderate price from all who are anxious to obtain it', argued Lord Goderich, 'instead of being injurious to the interests of those who desire to become settlers on the crown lands, would be found calculated to promote their success no less than the welfare and prosperity of the province at large.' Such was the case because if land were free, people would acquire far more than they could cultivate and thus much land would lie idle. If they were forced to earn enough to buy land by constructing the transportation infrastructure from which they would later profit it would progress more quickly; if they were forced to work for agricultural wages, they would learn Canadian techniques. Systematic colonization was agricultural education. On the other hand, a policy of free land grants would distort the colonial class structure. 'Without some division of labour, without a class of persons willing to work for wages, how can society be prevented from falling into a state of almost primitive rudeness, and how are the comforts and refinements of civilized life to be preserved,' Goderich asked rhetorically?32

In 1834, a huge tract of Crown Land, most of it in the Eastern Townships, was sold to the British North American Land Company. The action was one major source of contention in colonial politics, but it had the thoroughgoing support of the Colonial 
Office and large sections of anglophone capital in England and Canada. Edward Gibbon Wakefield was an unofficial member of the Durham mission, although his notorious past blocked his official appointment and increased the controversy surrounding the mission. Papineau, for instance, referred to Wakefield, convicted of seduction, and his fellow Thomas Turton, convicted of incest, as two men from 'les vomitoires des prisons. ${ }^{33}$ But Wakefield served as unofficial head of the mission's investigation into colonial lands policy. After the conclusion of the Durham mission, Wakefield would return to what was now Canada East and purchase Edward Ellice's Beauharnois seigneury. He served as a Canadian Member of Parliament.

When Joseph Lancaster claimed to be dragged to the poll to vote for the Tory Bagg in the 1832 election, the man holding one of his arms was Robert Armour, Jr. Armour's father was proprietor of the Montreal Gazette, sometimes King's Printer, and tightly connected to the network of anglophone capital and political conservatism in Montreal through banking, fire insurance, the gas lighting company, the British American Land Company, the St. Andrew's Society, the Mechanics' Institute and the Constitutional Association among others. With his partner John Ramsay, Armour Sr.'s publishing company of Armour \& Ramsay was a main importer and printer of schoolbooks in the colony, including the first versions of the Irish National schoolbooks in the $1840 \mathrm{~s}$. Robert Armour Jr. studied law in the office of Samuel Gale, first president of the Montreal Infant School Society, and was admitted to the bar in 1829 . He worked in a variety of venues in the 1820 s and early 1830 s, practicing law, but also compiling an annual gazetteer and guide to Montreal that the Gazette printed, seeking the appointment to prepare a digest of the provincial statutes and perhaps working in the Legislative Council Office. In 1832, after some controversy, his father engineered his appointment as registrar, clerk and treasurer to the Montreal Trinity House, on whose board Armour Sr. sat, and the son's performance bond was endorsed by Peter McGill. Armour Jr. also distinguished himself as the only public officer on the list of members of the paramilitary Montreal Rifle Corps, formed in late 1835 to protect civil liberties against the supposed threat of insurrection, and disbanded under pressure from Gosford early the following year.

Armour Jr.'s connections to educational matters are evident first in 1830 when he appeared as a signatory to a petition in support of a demand for financial aid for the British and Canadian School in Montreal. His brother Shaw was also involved, and the school had the support of a large section of the Montreal Protestant elite. He also tracked elementary school expenditure, either in some capacity in the Legislative Council Office, or for his Montreal gazetteer. After the formation of the British American Land Company, Armour interested himself in the development of the Eastern Townships, moved to Sherbrooke and founded a newspaper. He was involved in a variety of development schemes, but died at age 39 in 1845 .

The Lower Canada Special Council moved in early summer 1839 to give effect to the recommendation in the Durham report that the colony be divided into three districts for educational purposes and that, as a preliminary for new legislation, an inspector be appointed to investigate the condition of education. Robert Armour Jr. was appointed and despatched with a letter of introduction from the acting governor's sec- 
retary to consult with John Neilson in Montreal and to collect relevant state papers for the preparation of his official instructions. Secretary Gouldie noted that there was a substantial sum available for schooling. The initial plan of the Special Council was to use the money in building and repairing school houses and for paying teachers an annual salary of about $£ 130$, about three times what most of them had earned under the Trustees' Act, provided they passed a qualifying exam. 'I understand that in the disaffected parts of this district,' Gouldie wrote, 'the habitans are very anxious for the establishment of Parochial Schools and attribute in a great measure their late troubles to a want of education. ${ }^{34}$

Armour traveled throughout the parishes of the Montreal district, noting how many school districts had been created by the School Acts, how many had actually been in operation and how many remained active three years after the government grant had ceased. He attempted to track the fate of school buildings and furniture and he reported not only on how many school districts would suffice in each area, but on where it would be possible to establish superior schools. Armour's most enthusiastic endorsements were reserved for the schools built by the British American Land Company in its planned settlements. He denounced the backwardness of the French Canadian parishes and refused to take any account of the many small private schools organized by young women in the absence of government support. Finally, the Special Council also set Armour to settling an outstanding score with the former patriote MPP Louis Archambault who had been accused before the Rebellion of misappropriating colonial school monies. ${ }^{35}$ This initiative was one more form of proof for the triumphant Tory faction that the attempts at colonial schooling of the 1830s were completely useless and that an Irish-style reform was urgently needed.

\section{Conclusion}

It is a sociological truism that everyone is connected to everyone else in social networks at any given historical moment. These typically have very few degrees of separation among their nodes. Writing the history of educational networks in Lower Canada could be an exercise in describing social connections throughout the colony. I chose to begin with Alexis de Tocqueville from an interest in connecting educational politics in Lower Canada to political groups and to political interrogations on the other side of the Atlantic. A different starting point would open up different areas of the network. I have dealt with men of the dominant classes almost exclusively, and selectively. I could have begun with the members of the urban school society boards, for instance, and then have traced elite connections around schooling and around other activities to locate the schooling project more clearly. Yet one could begin from many other points and see other connections. For instance, one could start with the network opened up by the Buller Education Commission and find men and some women of a different social class than the urban elite. Buller and Dunkin's enquiry is helpful in this regard. They faced a sociological problem, in that there were very few regular connections between central authority and local sites in Lower Canada, and fewer still after the Rebellion had disorganized authority relations in many localities. How to find inform- 
ants? They tried to draw up lists of influential local residents who might be willing to answer questions - justices of the peace, for instance - but the attempt proved unsatisfactory. Finally they decided to create a bundle of questionnaires, to mail them to some known person in a locality; to mail a list of instructions for completing the questionnaires to a second person; and to name several other people on the outside of the questionnaire package. Those named were encouraged to convene with others 'in the know' to fill out the questionnaires together, in what would have amounted to a mini local commission. There were 284 bundles sent and well over a thousand people named. Correspondence came back to the commission with accounts of additional people.

From such a network, we would hear other accounts of education and schooling than those bandied about in political theory or central administration. We could hear a dissident group of settlers in Inverness township who claimed that the local justice of the peace and minister had used the school monies to hire one of their daughters to teach a few children in a shack, while the settlers had no school of their own. Here the most important question was not religion or ethnicity, but rather control over the stove that made it possible to conduct school in winter. ${ }^{36}$ In Durham's correspondence, we can hear Stephen Randal, former editor of the Hamilton Free Press and publisher of Randal's Magazine, who was hired to teach at the Shefford or Frost Village Academy in 1838. Unlike those who had great hopes for an Irish-American hybrid school system for Lower Canada, Randal claimed the American-style system produced bad schoolhouses, bad teachers, and bad books. Almost all the men in the Eastern Townships could read and write, but for all the use they made of it they might as well have been ignorant. But the Assembly's schools had been no better. Under them, schooling in his neighbourhood had been 'rendered dogcheap', and so 'it was of course little better than dog's learning. ${ }^{37}$ How far such accounts made their way through the network I have described 'would be worth digging into more deeply.'

\section{Notes}

1 Inspection, for instance as I show in Curtis, Bruce. True Government by Choice Men? Inspection, Education, and State Formation in Canada West. Toronto: University of Toronto Press, 1992.

2 See ----. First Report of the Montreal Infant School Society, for 1830. CIHM \#35991. Montreal: Workman and Bowman, 1831. For their English correspndence, L[ibrary and A[rchives] C[anada], RG4 B30 11, 1 August 1835. On Wilderspin,McCann, Phillip. "Samuel Wilderspin and the Early Infant Schools." British Journal of Educational Studies 14.2 (1966): 188-204.

3 O'Connell, Maurice R. "O'Connell and the Spanish Civil War, 1834-39." O'Connell: Education, Church and State. Proceedings of the Second Annual Daniel O'Connell Workshop. Ed. Maurice R. O'Connell. Dublin: Irish Pub. Ad., 1992. 35-9.

4 Bergeron, Gérard. "L'interlude canadien pendant le voyage d'Amérique (1831) d'Alexis de Tocqueville et de Gustave de Beaumont." The Tocqueville Review (1993): 127-40. de Tocqueville, Alexis. Democracy in America. Toronto: Knopf, 1994.

---. Voyages en Sicilie et aux États-Unis. Oeuvres Complètes. Ed. J.-P. Mayer. $4 \mathrm{e}$ ed. Vol. V pt.1. Paris: Gallimard, 1957. Leclercq, Jean-Michel. "Alexis de Tocqueville au Canada (du 24 août au 2 septembre 1831)." Revue d'histoire de l'Amérique française 
22.3 (1968): 353-65. Vallée, Jacques, ed. Tocqueville au Bas-Canada. Montréal: Éditions du Jour, 1973.

5 The letter of introduction, dated 24 August 1831 is in LAC MG24 B1 7, Mondelet to Neilson, and reads: 'Permettez que je vous procure l'avantage de connaître Messrs de Beaumont \& de Tocqueville que leur mérite \& la mission dont ils sont chargés par le Gouvernement Français, recommandent assez. Je ne puis mieux faire que d'adresser ces deux messieurs qui voyagent pour connaitre le pays et ses habitans, à un homme comme vous qui pourrez assurement leur donner des renseignemens intéressans \& utiles'.

6 Tocqueville, Democracy, 430n.

7 Neilson, John. Rapport du Visiteur d'Ecole pour les Comtés de Bellechasse, L'Ilet, Kamouraska et Rimouski. à L'Honorable Chambre d'Assemblée du Bas-Canada, assembleé en Parlement. Québec: Lower Canada, Legislative Assembly, 1831.

8 Their manuscript report, which includes a detailed questionnaire, is in LAC RG4 A1 448 22 January 1835.

9 Mondelet, Charles. Letters on Elementary and Practical Education. To which is added a French translation. Montreal: John James Williams, 1841.

10 Dunkin, Christopher. "British American Politics." The North American Review 39.105 (1839): 373-431.

11 de Tocqueville, Alexis. Voyages en Angleterre, Irlande, Suisse et Algérie. Oeuvres Complètes. Vol. V. Paris: Gallimard, 1958, 169 ff. My translation. 'Civilization' means the growth of commerce and the division of labour.

12 de Tocqueville, Alexis. Correspondance Anglaise: Correspondance d'Alexis de Tocqueville avec Henry Reeve et John Stuart Mill. Oeuvres Complètes. Ed. J.-P. Mayer. Vol. 6 pt.1. Paris: Gallimard, 1957. ---. Voyages en Angleterre, Irlande, Suisse et Algérie. Oeuvres Complètes. Vol. V. Paris: Gallimard, 1958. On Irish popular learning, McManus, Antonia. The Irish Hedge School and its Books, 1695-1831. Dublin: Four Courts Press, 2002.

13 In personal conversation, the educational historian Phillip McCann reported a visit to the garden in 1958, just as it was demolished. William Thomas claims in The Philosophic Radicals: Nine Studies in Theory and Practice, 1817-41. Oxford, 1979, claimed that Bentham planned to build the school but was diverted into writing Chrestomathia instead.

14 There is a contemporary account in anon. Rapport d'un Québecois sur quelques Écoles Élémentaires du District de Quebec. CIHM \#21452. n.p.: n.p., 1834. The National school in Quebec also offered industrial training, using part of the proceeds of child labour to pay its costs; see ----. Regulations for the Quebec Central Schools For Boys and Girls. Conducted upon the Madras System. Quebec: National and British Printing Office, 1820.

15 On Perrault, the excellent Jolois, Jean-Jacques. Joseph-François Perrault (1753-1844) et les origines de l'enseignement lä̈que au Bas-Canada. Montréal: Les Presses de l'Université de Montréal, 1969. Girod declared his gratitude for His Majesty's legal protection after arriving in the colony in 1831 by offering to share his discovery of a method for remagnetizing ships' compasses; LAC, RG4 A1 367, Girod to Aylmer, 25 October 1831; MG24 A27 3415 November 1837.

16 LAC RG4 A1 307, 321, 322, Perrault to Kempt, 15 January 1830; opinions of Crown Law Officers, 12 May 1830; Executive Council Minutes, 6 May 1830; 336, Lancaster to Kempt, 9 September 1830.

17 For Lancaster in Canada, Curtis, Bruce. "Joseph Lancaster in Montreal (bis): Monitorial Schooling and Politics." Historical Studies in Education/ Revue d'histoire de l'éducation 17.1 (2005): 1-27. There is additional correspondence I have since discovered in LAC RG4 A1.

18 de Tocqueville, Voyages en Angleterre, 56-7; my translation.

19 Musée de la Civilisation, Fonds du Seminaire de Québec, Polygraphie 3. n.71

20 Ellice to Lord Howick, 24 July 1836 [copy].

LAC R2823-0-1-E Edward Ellice and Family Papers. 
21 Tocqueville, Correspondance Anglaise, 81; my translation.

22 Durham, Lord. Lord Durham's Report on the Affairs of British North America. Ed. C.P. Lucas. 3 vols. Oxford: Calrendon Press, 1912.

23 On Buller see Haury, David A. The Origins of the Liberal Party and Liberal Imperialism. The Career of Charles Buller, 1806-1848. New York: Garland Publishing Inc., 1987.

24 Although schooling was no.82 in a long list of official instructions, see LAC CO42/266 17 July 1835.

25 LAC CO42/269 n.d. [November] 1836.

26 Curtis, Bruce. "The Buller Education Commission; or, The London Statistical Society Comes to Canada, 1838-42." The Age of Numbers/L'ère du chiffre. Eds. J.-P. Beaud and J.-G. Prévost Quebec: PUQ, 2000. 278-97. ---. "Irish Schools for Canada: Arthur Buller to the Bishop of Quebec." Historical Studies in Education/ Revue d'histoire de l'éducation 13.1 (2001): 49-58. ---. "State of the Nation or Community of Spirit? Schooling for Civic and Ethnic-Religious Nationalism in Insurrectionary Lower Canada." History of Education Quarterly 43.3 (2003): 324-49.

27 LAC MG24 A 27, Gosford to Durham, 30 June 1838. Derbishire to C. Buller, 13 \& 15 June goes on at length about managing the press.

28 Dunkin's draft report on the schools is in LAC RG4 A1 603, n.d. 1840; his manuscript report on the Jesuits' Estates is in the McGill University Rare Books Library, Protestant Education in Quebec collection; his essay is Dunkin, Christopher. "British American Politics." The North American Review 39.105 (1839): 373-431. See also, Curtis, Bruce. "Public Education and the Manufacture of Solidarity: Christopher Dunkin's Design for Lower Canada." Histoire sociale/Social History 35.70 (2002): 449-70.

29 University of London, Register of Students, Sessions 1828-29. My thanks to Mike Haan for ferreting out this reference.

30 Thomas, Philosophic Radicals, $375 \mathrm{ff}$.

31 Marx, Karl. "The Modern Theory of Colonization." Capital. A Critique of Political Economy. Vol. 1. Harmondsworth: Penguin Books, 1976 [1867]. 931-40.

32 Goderich to Aylmer, 21 November 1831, reproduced in Christie, Robert. A History of the Late Province of Lower Canada. Parliamentary and Political. From the Commencement to the Close of its Existence as a Separate Province. Vol. 3. 6 vols. Montreal: Richard Worthington, 1866, 374-80n.

33 Quoted in Lamonde, Yvan, and Claude Larin, eds. Louis-Joseph Papineau. Un demi-siècle de combats. Interventions publiques. Montréal: Fides, 1998, 516.

34 LAC MG24 B1 Gouldie to Neilson, 9 July 1839.

35 Laudatory accounts in LAC RG4 B30 114, returns for the Townships of Ascot, Bury and Sidgwick; for Archambault, Montreal Gazette, 30 January 1836; Province of Canada, Sessional Papers, 4-5 Vic. Appendix I, 1841.

36 LAC RG4 B30 110, 17 November 1838.

37 LAC MG24 A27, 26 n.d. 1838. 